\title{
Representation and the Pedagogical Reduction of the World
}

\author{
David Lewin \\ University of Strathclyde, UK
}

\section{INTRODUCTION}

If names or concepts make things present, what need is there for representation? Do representations make inaccessible things accessible? If we suppose that the self and the world are mediated by way of representations, as Paul Ricoeur put it "through signs, symbols, and texts,"1 we stimulate valuable considerations for philosophers and educational theorists. Ricoeur's contribution here is significant since, along with Heidegger and Gadamer, his work is characterized as philosophical hermeneutics. ${ }^{2}$ The relevance of this tradition can be found in the articulation of the interpretive condition of human being and, from this, an account of education becomes possible that understands the reduction, interpretation, and representation of the world to the young. In short, education is essentially hermeneutical. In what follows, I explore questions around pedagogical representation and their relation to the general problems of representation by way of two pedagogical texts: Comenius' Orbis Sensualium Pictus and the Zen Buddhist training text, The Ten Bulls.

\section{THE PHILOSOPHICAL NEED FOR REPRESENTATION}

Discussions of the nature of representations, signs, symbols, and other related concepts, preoccupy modern philosophers. These discussions generally concern relations between what might be called the visible and invisible, appearance and reality, phenomena and noumena, or, in Wittgensteinian terms, between sense and nonsense. Although central to these discussions, Wittgenstein himself presents a complicated case, given his shifting views of language and representation and the extent to which the mind can represent the world by way of meaning. His category of the senseless (sinloss), which he uses to point to that which grounds meaning and sense in the first place, allows him to speak 
both of language as representing, but also of bearing witness, as he puts it, of showing and saying. ${ }^{3}$ In what follows, I want to indicate that which transgresses language and representation, and so another form of this essay could, I suspect, be developed through Wittgenstein's categories. My approach already involves a productive paradox: by acknowledging that I hope to make some sense of that which lies beyond the frontiers of sense. From this point of view, explanation, signification, and representation entail a correlation between something absent (or invisible) and something present (or visible). It is noteworthy that educational theory tends to gloss over fundamental questions of representation, especially given the fact that representation could arguably be the central pedagogical concept; it may be the key pedagogical insight to apply to wider philosophy. ${ }^{4}$ By educational representation I mean that education is not just the haphazard presentation of the world to the young, but rather could be said to be the intentional representation of aspects of the world, albeit interpreted and reduced to make for structured learning possibilities. The definition of education as entailing intentional pedagogical reductions of the phenomenal lifeworld will need some unpacking, as will its implications.

First we could ask why we should need representations to refer us to any thing? In one sense, the simple presence of an object might be enough. I do not need a picture of my mother when we are together. When she is absent her representation hanging on the wall acts to make her presence felt. In an age of tele-presence (e.g. Skype; Facetime etc.) and other technological mediations, general assumptions around the stability of presence and absence are undone, and we are right to wonder what presence could possibly mean. The presence of less concrete things, like music, beauty, or justice, require mediation in a richer sense, through what Shakespeare in A Midsummer Night's Dream has Theseus call "local habitation and a name." 5 The manifestation of the universal idea through particular concrete objects is supposed, through the Neoplatonic lens of Shakespeare, to open a window to being itself. ${ }^{6}$ This suggests that the representation of the thing makes it visible, and that this is "making present" as poiesis. The focus of learning should, from this point of view, be the universal, since an apprehension of this would unlock a knowledge of (if not familiarity 
with) all things.

As we will see, the universal intention behind textbooks such as Comenius' Orbis Sensualius Pictus suggests such a universalist orientation. These ideas indicate that pedagogical representations are less about simply making present what is absent, than about inducting children into universal knowledge by way of the symbolic lifeworld through mathematical number, textual signs and metaphysical ideas. Indeed, as Heidegger points out, mathemata originally refers to that which is teachable, and is, then, the substance of all education. On that basis, Plato's academy requires a commitment to geometry, to symbols and representations. ${ }^{7}$ These reflections on the philosophical place of representation in education introduce, and lend some support to, questions developed by one of the most important figures in post-war German educational theory, Klaus Mollenhauer. Mollenhauer examines questions around pedagogy and upbringing with a clarity and directness seldom evident in Anglo-American writing. It is in his best-known work Forgotten Connections, translated by Norm Friesen in 2014, that Mollenhauer makes the key distinction between presentation and representation. ${ }^{8}$

\section{THE ROLE OF REPRESENTATION IN EDUCATION}

Representations are pedagogically essential. As Mollenhauer puts it: "[w]e long ago accepted that the realm of schooling consists of a huge montage of images and representations which are not 'the things themselves' but that instead 'point out' things and phenomena." "For Mollenhauer this pointing out on its own is not quite enough. Representation does not just fully and comprehensively reflect what it represents for obvious reasons. Therefore, the need for representation in education arises out of its ability to structure and frame a world too vast and confusing in itself. The emergence of explicitly pedagogical representations of the world through the textbook around the time of Comenius reflects a fundamental shift within our educational history. Mollenhauer's narrative distinguishes between the presentation of the world to the child, where pedagogy is more direct and related to the immediacies of upbringing, prior 
to the more consistent construction of childhood as a stage of development on the way to full humanity. This allows Mollenhauer to make a systematic distinction between the immediacy, and not always intentional dimensions, of upbringing as presentation, and the more intentional but also more mediated forms of representation in school. Mollenhauer refers to Comenius' Orbis Sensualium Pictus (generally translated as The Visible World in Pictures, though this translation raises a few problems ${ }^{10}$ ) as an example of the emergence of the realm of pedagogical representation.

Any representation involves some kind of framing of the world that draws attention to certain features of interest or significance, while obscuring others (of less interest, or simply too complex at a given pedagogical stage or moment). This is because representations do not just make close/present what is distant/absent. Nor do representations only refer directly to something else (e.g. the map does not only refer directly to the territory which it maps). On modern digital maps the aspects of significance or meaning are layered by smart use of imaging technologies (e.g. terrain, transport, traffic and so on). These aspects of representation reveal some characteristic reductions that representations generally involve. The user of the digital map can make choices about which layers of information to include or exclude, but the structure of mapping itself, and the layers available to the user are not in his or her control. There is, then, the reduction made by the user, and in addition, a set of reductions also imposed on the user by the form of the technical interface which, by foregrounding certain functions, conceals that which the designers deem to be distracting or problematic. We might say, then, that digital interfaces perform a technical reduction: the world is mediated to the user through technical objects that reflect the (anticipated) desires of the user.

Educational representations involve a pedagogical reduction: this reduction might entail a simplification of certain aspects of the world, or of a complex set of actions or understandings in order to develop skills and knowledge in an intentional and organised way. Textbooks offer clear examples of pedagogical reductions. The complex and contested nature of any domain of knowledge is secondary to the clear and simplified account of that domain. 
Official knowledge is inevitably framed, structured, and reduced to facilitate learning, particularly in the context of compulsory mass education. While there are many political and ethical questions concerning the interests that are served by official knowledge, someone has to write the textbook. Good students don't take those representations to be complete, and good teachers are constantly exploring how and when to draw attention to the inherent tensions and contradictions contained within the textbook encounter. This could be regarded dialectically: that knowledge must be established through a rudimentary thesis, which then must be called into question, and refined into a synthesis that becomes a new thesis to be called into question. In addition to the pedagogical reduction that allows for the dialectical process to begin, representations also facilitate what can be termed "pedagogical rehearsals." These refer to the spaces of education that offer students the opportunity to rehearse complex actions and knowledges before they are performed for real. It is important to note that rehearsal and reduction are central features of education, rather than inauthentic distractions to be avoided or apologized for. Recognizing the positive role of reduction and rehearsal is vital because it has become fashionable among progressive educators in particular, at least since Dewey, to claim that education should strive for authentic experience of the world, and that the educational space should be, as far as possible, continuous with, or indistinguishable from, a putative real world. Pedagogical reductions and rehearsals appear to some as dimensions of inauthenticity. From this perspective, learning should aspire to be "real world" rather than abstract or rehearsed. Contrary to this desire for "authenticity," I suggest that education should be taken as intrinsically "inauthentic": that the pedagogical reduction is not to be avoided, but to be recognised as key.

It is essential to the representational reduction that, in selecting what is of interest, it determines on behalf of the student what is worthy of attention and interest. Much as progressive educators might seek to disavow the authority of the teacher in determining the orientation of the student in this way, or critical pedagogues might draw attention to the hegemonic nature of this selection process,${ }^{11}$ this dimension of pedagogical reduction seems to be hard to avoid, and indeed, something that the student hopes for, if not quite demands of the 
teacher. It is a significant service to the student that the pedagogical reduction of the world takes place so that an entry point to education is possible. So it is clear that this reduction is intended to make some aspect of the world available to the student, despite the fact that reduction and representation are sometimes associated not with revealing the world, but with concealing it.

\section{WHAT'S WRONG WITH REPRESENTATIONS?}

A world of appearances like that revealed in the movie The Matrix or by Plato's Allegory of the Cave might be a comfortable place. However, philosophers have long had an ambivalent relation to the idea of an appearance as contrasted with a real world, leading to various images of demystification of education from the ascent of the mind in Plato's cave, to the absurdly overdramatic fight scene in John Carpenter's film They Live, where the protagonist goes to great lengths to have his friend share his experience of demystification by putting on glasses that reveal the truth, while the friend resists every effort to have the glasses forced over his vision. Critical pedagogy, as a progressive educational movement, has a more direct concern with demystifying the socio-political interests and hegemonies that govern the pedagogical reduction. It is perhaps simpler to rail against those authorities governing pedagogical reductions in general, than to offer a rationale for different choices concerning a necessary reduction. It is too easy to interpret critical pedagogy as lifting the veil, or revealing the truth, without recognizing that this always entails a different reduction: as Heidegger put it, every revealing is also a concealing. ${ }^{12}$ This is to recognize our hermeneutic condition: that interpretation, reduction, and education belong together. The danger is that critical pedagogy would seek to do away with the pedagogical reduction itself, thereby failing to recognize the constructive mode that reduction entails. This suspicion of representation seems predicated on too simplistic a binary between appearances and the real. The ambivalence towards representation goes back at least to Plato's (ironic?) banning of the poets in The Republic.

Poets are problematic, first, because they imitate aspects of the world, 
and second, because they rely on rhetoric to do so. In tension with this account of mimesis is Plato's argument that the mind ascends from the world of senses to mathemata. Mathemata might be understood here as being that which is intrinsically teachable because it already exists in the soul and requires remembrance (anamnesis). The process of remembrance, of learning what we already "know," presupposes the ontology outlined earlier, in which the learner recalls universals by way of encounter with concrete objects; learning as recollection and ascent. One subsequent question occurs: are representations of things mimetic or mathematical? Do representations imitate imitations (as Plato suggests of the poets in Book X), or do they make universals accessible through recollection. In a different register, but with related concerns, we might ask with Heidegger whether representations challenge forth the world in terms of the projecting subject's desire to control, or do they bring forth (poiesis) the world the subject can participate in. ${ }^{13}$ Heidegger makes many enigmatic allusions to this key distinction between representational thinking and real thinking. For Heidegger, the problem with representational thinking is not that human beings use representations to mediate the world around them, but that the representations are regarded as sufficient in themselves, referring to nothing beyond themselves (which sounds rather like Wittgenstein's problem with Russell's account of language as saying). Without a recognition of the limitations of representation, knowledge can become fragmented and parochial, rather than universal. But how are we to acquaint ourselves and our children with the universal? Comenius' text offers the pedagogical reduction that makes everything present to the child.

\section{THE (IN)VISIBLE WORLD IN PICTURES}

First published in 1657, and being one of the first pedagogical works for young children, Comenius' Orbis Sensualium Pictus is a curious text when it comes to the question of representation, for, despite its title (usually translated as The Visible World in Pictures), it seems concerned with both the invisible as well as the visible (sensualium). It might be anachronistic to expect the visible world to mean today what it meant in 1657, but does not the text weave between the visible and invisible as Charles McNamara suggests? ${ }^{14}$ The structure of the book 
reflects the organization of the late medieval cosmos. After a brief exhortation to wisdom, the text addresses the reader to very concrete and visible matters. Beginning with what might be read as an early version of "Old Macdonald Had a Farm," drawings of different animals are presented along with their names and characteristic animal sounds (though requiring some imaginative translation: the dog grinneth, err the serpent hisseth, $s i$; etc.). This naming of the alphabet through the concretely visible is immediately followed by an analysis of God in himself (Blessed, everlasting, spiritual, and so on). McNamara says that the Orbis "abruptly shifts to the philosophical and the invisible, perhaps hoping that a firm grasp of ducks and mice is sufficient for understanding the divine." ${ }^{15}$ It could be asked whether God, heaven, and the soul might have been aspects of a "visible world" to the mid-seventeenth century child (or to Comenius), for whom the secular age is some way off. The text moves on to creation (heaven and earth) followed by the elements (fire, water, air, earth), and through a great list of objects, organized along the lines of the great chain of being in which everything has its cosmic place. ${ }^{16}$ This systematic representation of the world can be regarded as complete, as offering the child access both to the symbolic order of literacy, as well as to the universals that encompass everything. In order for everything to be present through a pedagogical reduction, the text mediates universals that are its real object.

\section{THE UNREPRESENTABLE}

So far, this paper has explored the view that education entails representation utilizing reduction to represent the visible world to the child. Is this account in tension with the category of the unrepresentable? The questions this essay attempts to raise are to do with the tensions between the pedagogical reduction of the world and the category of the unrepresentable. It is an open question as to whether unrepresentable things exist or what is meant by the claim that something is unrepresentable. At the level of logic, anything thinkable can be represented. Nevertheless, it is common to see the ultimate reference point of religion (God/truth/enlightenment) as that which resists, subverts, or denies attempts at representation. The logic of my argument boils down to this: if 1) 
education is essentially about representation, and if 2) there is something in the world that is intrinsically unrepresentable, then are we forced to admit that education has no place when it comes to the unrepresentable (e.g. the referent of religion)? Does this suggest that the unrepresentable referent of religion cannot be the object of learning within education? Or should we question the idea that education involves pedagogical reduction?

When we consider Comenius' text, we must realise that the line between the visible and invisible is not one that can be drawn by some kind of natural intuition or common sense. Perhaps reference to the term sensualium (sensual) suggests that the key distinction should be between that which can be represented to the senses, and that which cannot. Of course, translation of the text as The Visible World in Pictures is problematic, but I think something more can be said about these terms. John Milbank argues that to see the beautiful is to see the invisible in the visible. He claims that "[i]n the High Middle Ages, the possibility and experience of seeing the invisible in the visible, or of seeing the invisible as invisible ... was generally assumed and pervaded life, art and understanding." ${ }^{\prime 17}$ The invisible framed the visible and, in a sense, made it possible, made it visible. The point of this reference is to draw attention to a dialectic between the visible and invisible, or between the representable and the unrepresentable: they are relational, rather than absolute, terms.

God/truth/enlightenment is simultaneously unrepresentable and representable, simultaneously invisible and visible. This is because the visibility or representability of a thing is not a property of it as such, but is a relational property existing between the beholder and beheld. The act of making particular (visible) that which is universal (invisible) always entails a reduction that both reveals and conceals, and so is a process or relation that is never complete. This suggests that our human condition is betwixt and between, in motion among the visible and the invisible. But the phenomena of the visible world make the invisible visible. Again referring to Shakespeare's Theseus, we, like poets:

Doth glance from heaven to earth, from earth to heaven;

And as imagination bodies forth

The forms of things unknown, the poet's pen 
Turns them to shapes and gives to airy nothing

A local habitation and a name. ${ }^{18}$

\section{THE TEN BULLS}

I now turn to a text from Zen Buddhism to explore an alternative perspective on the questions of pedagogical representation and reduction. Notoriously difficult to systematize and rationalize, Zen Buddhism provides a strong contrast to the approach of Comenius, and yet the basic journey described by The Ten Bulls can be neatly summarized:

Way out of suffering $=$ eradication of afflicting passions $=$ transformation of the energy that flares in the passions into Buddha-Nature $=$ gentling the bull $=$ becoming human $=$ the realisation of the No-I $=$ the end of all fear $=$ insight into the nature of change $=$ deliverance $=$ insight into the way all things really are $=$ the end of suffering $=$ awakening. ${ }^{19}$

Is this way out an education as formation? This question might offer us a conceptual understanding of The Ten Bulls, but to go beyond the conceptual requires a particular pedagogical intervention that the text makes possible. The set of ten poems, pictures, and commentaries that forms the multi-layered text, uses the relations between a bull and a herder that arise during a process of taming or gentling the bull, relations that allegorize the various stages towards enlightenment. Although not regarded as a pedagogical textbook in the sense that Orbis is, it is intended to act pedagogically, offering a tool for, and representation of, stages of spiritual life. But since Zen Buddhism is particularly subversive when it comes to representations of the path to enlightenment, the approaches the text takes are more allegorical and metaphorical.

Many versions of the bull-taming pictures have been identified, ranging from 5 to 11 images. The most well-known version (which is today kept in the Shokokuji Temple, Kyoto) is that produced around 1450 by Shubun, a $15^{\text {th }}$ century Zen Monk and one of the most celebrated painters of the Ashikaga period. ${ }^{20}$ Shubun is thought to have copied the pictures from Kakuan, a $12^{\text {th }}$ 
Century Chinese Zen master. The images have long been a favourite training analogy for Zen Buddhist monks and are still used today. Each image is traditionally accompanied by three sets of poems, which address the Zen monks but also acquaint other interested readers with the fundamentals of Zen training. ${ }^{21}$

A brief sketch of the content is necessary. The first image is called "In Search of the Bull." It shows the herder looking lost, revealing the human condition as one of being in question, at odds with self and world, where the bull cannot be found. The second and third images show the stages of the herder discovering the bull's hoof prints and a brief perception of the bull itself. Stages four to six show the herder catching, taming, and riding the bull. This is followed by transcending the bull in the seventh image and the transcending the self and bull in the eighth. Following transcendence, the ninth image is called "reaching the source," and in the tenth, the herder returns to the world.

To say that the bull and herder represent different aspects of the self is both correct and misleading, since the text must be practiced: it must be read, meditated upon, and experienced. Buddhist teaching recognizes that the truth of enlightenment is not something to be told directly. So, on the one hand it is hard to say that the text represents anything; rather, it invites the practitioner into an approach or practice. Does this mean that the text does not perform a pedagogical reduction or entail representations? Clearly, the images and texts are, in some sense, representations. As a pedagogical device the text makes present through metaphor or allegory. On the face of it, this would seem simply like a representation. But unlike the numbered images in Comenius' textbook, where students can learn the names of visible things in their own language as well as Latin, the imagery and poetry of The Ten Bulls demands an interpretive act in a more explicit way. As spiritual analogies and metaphors often do, the text forces the reader to pay attention to the hermeneutic conditions of living and of learning. The reader has to consider how the text is to be read. The invisible is visible in the visible in this radical way. The paradoxical nature of the invisible being visible might even suggest that there is no invisible: that what you have in The Ten Bulls is superficially unrepresentable. 


\section{CONCLUSION}

The concern of this essay has been to develop some implications that arise from Mollenhauer's ideas around pedagogical representation and reduction. The tentative hypothesis has been around the category of the unrepresentable, which religious traditions generally have particular interest it. I have only begun the task of developing a systematic conception of pedagogical reduction in light of traditions that deny or complicate the idea of representation and reduction. Further questions could be developed about whether the unrepresentable is a coherent category at all, or whether the representational reduction is essential to education. The two texts discussed are oriented to representation from different ends. On the one hand, Orbis offers an apparently straightforward representation of the world, though raising significant difficulties when it comes to drawing a line between what is visible/invisible. On the other hand, the context of The Ten Bulls suggests a greater emphasis on the hermeneutical condition. The truth of representation lies somewhere in between.

1 Paul Ricoeur, From Text to Action, trans. K. Blamey \& J. Thompson (Evanston: Northwestern University Press, 1986), 15.

2 While Heidegger's work has received considerable attention among educational theorists in recent years, the specific contribution of philosophical hermeneutics, particularly that of Ricoeur, is seldom discussed.

3 See Anat Biletzki and Anat Matar, "Ludwig Wittgenstein," The Stanford Encyclopedia of Philosophy (Fall 2016 Edition), ed. Edward N. Zalta, https://plato. stanford.edu/archives/fall2016/entries/wittgenstein/

4 Mollenhauer provides some systematic treatment of the symbols for education, even if his point of departure is to bemoan the general absence of more discussions of the use of symbols in education: Klaus Mollenhauer, "The Function of the Symbol in Education," Phenomenology + Pedagogy 9 (1991): 356-369.

5 William Shakespeare, A Midsummer Night's Dream, Act V Scene I, available at http://shakespeare.mit.edu/midsummer/midsummer.5.1.html

6 For discussion of Shakespeare's Neoplatonism see Michael Whitmore, 
Shakespearean Metaphysics (London: Continuum, 2008).

7 Martin Heidegger, "Modern Science, Metaphysics, and Mathematics," in Basic Writings, ed. David Farrell Krell (New York: HarperCollins, 2008), 271305.

8 Klaus Mollenhauer, Forgotten Connections: On Culture and Upbringing, trans. N. Friesen (London: Routledge, 2014).

9 Mollenhauer, Forgotten Connections, 34.

10 Orbis Sensualium Pictus could be literally translated as the world of the senses in pictures or images.

11 Michael Apple, Official Knowledge (London: Routledge, 2014).

12 Heidegger's concept of truth (if that phrase is not too great a reduction) involves a creative retrieval of aletheia, translated as unconcealment, which emphasizes the hermeneutical condition since every revealing of what is, is also a concealing.

13 This draws on Heidegger's well known distinction between challenging forth and bringing forth, discussed in "The Question Concerning Technology," an essay which has had considerable impact upon recent discussions within philosophy of education.

14 Charles McNamara, "In the Image of God: John Comenius and the First Children's Picture Book," https://publicdomainreview.org/2014/05/14/inthe-image-of-god-john-comenius-and-the-first-childrens-picture-book/

15 McNamara, "In the Image of God." McNamara seems to miss the systematic reason for the inclusion of these sounds at the start of Orbis, namely that the student is introduced to the alphabet before proceeding to things visible.

16 Interestingly, this text does not introduce the student to mathematics or geometry.

17 John Milbank, "Beauty and the Sou," in Theological Perspectives on Art and Beauty, ed. John Milbank, Graham Ward, and Edith Wyschogrod (London: Continuum, 2003), 2.

18 Shakespeare, A Midsummer Night's Dream, Act V, Scene I.

19 Myokyo-Ni, Gentling the Bull (London: Zen Centre, 2001), 17.

20 See Daisetz Teitaro Suzuki, Manual of Zen Buddhism (London: Rider, 1974), 127-144. 
21 Myokyo-Ni, Gentling the Bull. 